\title{
5. Illuminating the cave names of Gundungurra country
}

\author{
Jim Smith
}

\section{Introduction}

Jenolan and Wombeyan are two of the most widely recognised Aboriginal placenames, while Tuglow and Colong are perhaps better known to bushwalkers and speleologists. These limestone cave complexes are in the country of the Gundungurra (also spelled Gandangara) speaking people. ${ }^{1}$ Their territory, which included the catchments of the Wollondilly and Cox rivers and some adjacent areas west of the Great Dividing Range, has one of the richest concentrations of limestone caves in Australia. As well as the four main areas listed above there are many small, lesser-known karst areas. These places were very important to the local Aboriginal people. It is a common misconception that they were afraid to go into dark caves. Jeremiah Wilson, who was appointed the first caretaker of Jenolan Caves in 1867, was interviewed in 1896 and said:

though he tried hard he could not ascertain the proper aboriginal name of the caves. He has never been able to induce an aboriginal to enter them, and does not believe the aboriginals knew of the interior Caves (Hoben 1896: 1247).

This was contradicted by the Gundungurra man Billy Lynch (c.1839-1913), who provided the Aboriginal name and also stated to the same interviewer:

Mr Jerry Wilson is wrong in thinking the natives did not know or enter the Jenolan Caves. They penetrated them as far as the subterranean water, carrying in sick people to be bathed in this water, which they believed to have great curative powers (Hoben 1896: 1250).

A.L. Bennett obtained from another Gundungurra man, Werriberrie (William Russell, c.1835-1914), the legend of 'Old Gareem the God of sickness and health' who created the medicinal water (morle-boc) within limestone caves. ${ }^{2}$ This was

\footnotetext{
1 Although Tindale (1974: 193) recommended the spelling Gandangara, and this is used by most linguists today, the spelling Gundungurra is preferred by the current organisations representing the descendants of the speakers of this language.

2 Camden grazier Alfred Leonard Bennett (1877-1942) recorded Gundungurra language and cultural information, mainly from William Russell, in the period c.1908-1914. His notes are privately held. They are unpaginated and nearly all undated. All references to Bennett in this paper are from these notes.
} 
used in particular to cure skin diseases. Obviously these healing areas had placenames which were well known to Gundungurra people. Unfortunately, in nearly all cases, the names for these places on our maps are not the names used by the original inhabitants and the commonly accepted meanings of the placenames are incorrect.

Some of the placenames referred to in this article are connected with the Gundungurra 'Dreaming' (gunyungalung) story of Gurangatch and Mirragan (Mathews 1908: 203-206). Gurangatch, a type of 'rainbow serpent', was pursued by Mirragan, a 'quoll-man', from a waterhole near the junction of the Wollondilly and Wingecarribee rivers to Joolundo waterhole on the Duckmaloi River, $170 \mathrm{~km}$ away. Gurangatch tried to hide from Mirragan inside both Wombeyan and Jenolan Caves.

\section{Jenolan}

The Jenolan Caves were first known by the non-Aboriginal names of Binda Caves or Fish River Caves. These were examples of 'naming by proximity', as both the Binda property and Fish River were landmarks passed by travellers on their way to the caves but still at a significant distance from them. The official name of 'Jenolan Caves' was gazetted on 19 August 1884 at the suggestion of government surveyor William Cooper (Havard 1933: 31). It is regrettable that the real Aboriginal name for the Caves was not ascertained at the time. While Jenolan is a Gundungurra placename, it belongs to a mountain $13 \mathrm{~km}$ from the caves. Mount Jenolan is one of the placenames published on Thomas Mitchell's map of New South Wales (Mitchell 1834). The Parish of Jenolan was later named after this prominent feature within it. 'Jenolan Caves' is really only shorthand for 'the caves within the Parish of Jenolan'. Even though three versions of the true Gundungurra placename for the caves had been published by 1900 (Binomil, Binoomea, Benomera, see Table 1), so much promotional literature had disseminated the name of Jenolan nationally and internationally that no one wanted to change it.

For a brief period, before the name of Jenolan Caves came into common usage, the caves were known by another Gundungurra word. An English traveller (Roberts 1886: 578) was told by the Jenolan Caves guide Fred Wilson in 1885 that the caves were called 'Jelanda'. This is a version of the placename recorded by R.H. Mathews as 'Joolundoo', 'Dyoo-lundoo' and 'Dyulloondoo' (Mathews 1908: 206; Mathews undated 8006/5/10 and 8006/3/10: 20) and in a local newspaper as 'Jelleindore' (Anon. 1907). 'Joolundoo' is the name of the waterhole where the climactic scene of the Gurangatch and Mirragan legend takes place. Research by the author has established that this waterhole is in the lower Duckmaloi River, 14 km from Jenolan Caves (Smith 2008: 185-199). Fred 
Wilson's conversation with his Aboriginal informant (or another non-Aboriginal intermediary) probably involved the usual type of misunderstanding where an Aboriginal word for one place was misapplied to another locality.

Table 1: Jenolan Caves.

\begin{tabular}{|l|l|l|}
\hline Original spelling & Meaning & Reference \\
\hline Binomil & & Hoben 1896: 1250 \\
\hline Binoomea & & $\begin{array}{l}\text { Padley 1892: 4, Trickett } \\
\text { 1899: 18 }\end{array}$ \\
\hline Benomera & 'holes' & Anon. c. 1899 \\
\hline Benomera & 'holes in a hill' & Anon. 1900a: 80 \\
\hline Bin-noo-mur & & Mathews 1908: 205 \\
\hline Benuma & 'big hole in the ground' & Hanrahan 1909:1 \\
\hline Benumera & 'hole in the hill' & Bennett c. 1908-14 \\
\hline
\end{tabular}

Source: The author.

Today, promotional and educational material about Jenolan Caves usually includes a reference to the original Aboriginal placename. However, it is nearly always published in Trickett's 1899 spelling of 'Binoomea'. The two vowels at the end are unlikely to reflect the Gundungurra sound of this word. This may be close to 'Binumirr' (Harold Koch, pers. comm. May 2013). The meanings attributed to it have the common theme of 'holes'. It is quite possible that there are other places in Gundungurra country where there were 'holes' in the landscape that were also called 'Binumirr' . One possibility appears on Mitchell's 1834 map. Mount Bannemir, near Hanworth Creek, is not in limestone country but may have some type of 'holes' in it. It would be interesting if the placename turns out to have 'predicted' the existence of a geological feature it has in common with the place we call Jenolan Caves.

\section{The meaning of Jenolan}

Visitors to Jenolan Caves are told by the guides, and in promotional literature, that Jenolan means 'high mountain'. This was first recorded by the Mines Department surveyor Oliver Trickett (1899: 18). As the caves are actually at the bottom of a deep valley, some tourists probably query this apparently contradictory 'meaning'. The non-Aboriginal person who asked his Gundungurra informant about the meaning of Jenolan (the name of the mountain distant from the caves) appears to have been given a descriptive, topographical or associative meaning. These have also been termed 'connotative' or 'affective' meanings (Amery 2002: 167). Popular books of mixed Aboriginal words from all over Australia, and the folklore of local community stories of placename meanings, contain many 
of these topographical and environmental descriptors. They have become established where there was mutual misunderstanding between Aboriginal people and early settlers about what was being asked with the question 'What is the meaning of [the local placename]?'. Aboriginal people realised that their white interrogators were not usually interested in the etymology of placenames and their cultural associations but were only looking for an English phrase to associate with the Aboriginal words. This occurred right across the continent, with a Western Australian researcher commenting:

Part of the reason why these spurious etymologies arise is explicable if it is realised that 19 th and 20th century recorders, because of their superficial understanding of Indigenous cultures and languages, often took attributes ascribed to a place by Indigenous informants as the derivation of its name (Gerritsen 2010: 1).

R.H. Mathews attempted to understand the etymology of Jenolan. One of his notebooks has this cryptic analysis: 'Jeno'lan, Jenno-wullan, caves (two feet or Bullen feet?)' (Mathews undated: 8006/3/7: 71). To decode this, it is useful to look at Bennett's records: genna or geno for 'foot' and jenolan, said to mean 'a man with a big foot'. The Gundungurra word for 'two' is bulla and the creator ancestors were called the bullens. In Gundungurra mythology the Bullen brothers created human beings during the gunyungalung, devised their initiation ceremonies and travelled the land destroying the many gubbas who preyed on people (Mathews 2003: 29-32). Mathews was apparently not able to distinguish whether bulla or bullen was incorporated into the four syllable version of Jenolan. In the Gundungurra language, where the second part of a compound word that begins with a $b$ follows a vowel or dipthong, the $b$ is changed to a $w$. The two words jenno and bullen cannot be combined as jennobullen and the combination was sounded as jennowullan. ${ }^{3}$

It is possible that, during the wanderings of the Bullen brothers, the landscape feature of Mount Jenolan was created. As their travels were extensive, there may be other places called 'Jennowullan' in Gundungurra country and, in fact, one other is known. Mount Genowlan (spelled 'Geenowlan' in some early records), near the Capertee Valley, is $78 \mathrm{~km}$ from Mount Jenolan.

\section{Wombeyan}

Wombeyan Caves are 'connected' to Jenolan Caves, as they are both major landmarks on the journey of Gurangatch and Mirragan during the gunyunggalung. Gurangatch reached Wombeyan by making a tunnel for himself.

3 For other examples of this see the section on adjectives in Mathews 1901: 144. 
On reaching the source of Jock's Creek, he burrowed under the range, coming up inside of Wam-bee-ang caves, which are called Whambeyan by the white people, being a corruption of the aboriginal name (Mathews 1908: 204).

Table 2: Wombeyan Caves.

\begin{tabular}{|l|l|l|l|}
\hline Original spelling & $\begin{array}{l}\text { Date of } \\
\text { Publication }\end{array}$ & Meaning & Reference \\
\hline Whambeyan & 1862 & & Nurse 1982: 2 \\
\hline Wambian & 1865 & & Nurse 1982: 2 \\
\hline Whombeyan & 1868 & & Nurse 1982: 2 \\
\hline Wombeian & 1868 & & Nurse 1982: 2 \\
\hline Wambiang and Wambeean & & & $\begin{array}{l}\text { Mathews undated } \\
8006 / 3 / 10: 18\end{array}$ \\
\hline Wam-bee-ang & & & Mathews 1908: 204 \\
\hline Wombeyang & & & Bennett c.1908-14 \\
\hline
\end{tabular}

Source: The author.

There are many early renderings of this placename (see Table 2). Bennett's spelling 'Wombeyang' may be closest, but should perhaps be spelled as 'Wombeeyang' to emphasise the long ee sound of the middle syllable. Only Bennett recorded a meaning. As it was obtained directly from his Gundungurra informant William Russell, the meaning of Wombeyan as 'tunnel' is probably authentic. Although all caves could be looked at as 'tunnels', it is possible that the Wombeyan Caves were named after their association with the tunnel created by Gurangatch. It is of interest that, even after more than one and a half centuries of speleological explorations of Wombeyan Caves, the tunnel connecting them with Jock's Creek has not yet been found. It may not actually exist, since Aboriginal mythology often used the device of underground travel to account for a 'Dreaming' being manifest at different locations (Harold Koch, pers. comm. May 2013).

There is the usual variety of incorrect 'meanings' published in popular 'Aboriginal words' books and tourist literature. These include 'caves in the hills' (Thorpe 1927: 15), 'gigantic kangaroo' (McCarthy 1959: 17) and 'grassy flats between two mountains' (Henderson 1985: 50).

Many of the individual caverns within the Wombeyan complex were given Gundungurra names by the first government appointed caretaker of the caves Charles Chalker (1845-1924). These were 'Wollondilly', 'Mulwaree', 'Guineacor', 'Bullio', 'Kooringa' and 'Miranda' caves. The first three are the names of local rivers and Bullio is a nearby locality. 'Kooringa' is a word of undocumented origin that could be a local placename. 
Indigenous and Minority Placenames

'Miranda' is a commemorative name. Wombeyan Caves lie in the country of the Burra Burra clan of the Gundungurra speaking people (Smith 1992: 4-9). In the 1830s the leader of this clan was Murrandah (c.1788-1849). His breastplate, with the words 'Murrandah, Chief of the Burra Burra tribe' is in the Camden Museum. His name was anglicised to Miranda or Maranda. Charles Chalker's grandfather William Chalker (c.1775-1823) had lived in the district since 1821 and possibly knew Miranda personally.

\section{Colong Caves}

The naming of Colong Caves is another example of 'naming by proximity'. Two early names for the caves were Kowmung Caves and Bindook Caves, after the nearby Kowmung River and Bindook Highlands. The Aboriginal name for these caves does not appear to have been recorded.

Trickett wrote in his official report on the caves:

I beg to suggest that they be called the Colong Caves after Mount Colong, a conspicuous landmark in the vicinity. The name is derived from the native word "Colung", signifying the home of the bandicoot (Trickett 1900: 211).

The scattered caves of the Colong Caves complex are all at least two kilometres from Mount Colong. Trickett's suggested meaning is not supported by several other independent sources (see Table 3) which confirm that Colong is the Gundungurra word for 'wombat'. Today, the first vowel of Colong is pronounced with a short $o$ sound. However, those recorders who are known to have spoken directly to Gundungurra speakers, Mathews, Hoben, Feld and Bennett have renderings with either $u$ or $o o$. It is of interest that descendants of the early pioneer families of the region and the older generation of bushwalkers often pronounce it as 'Coolong'. It is likely that Mathews' notebook (cited in Table 3) contains the most accurate rendering of the Gundungurra sound as gulang or kulang.

Unfortunately, the peak officially known as Mount Colong is incorrectly named. This confusion began in the 1830s with, for example, the 1833 New South Wales Almanac referring to 'Collong, which is a square-topped mountain visible from the Sydney Lighthouse' (reproduced in Anon. 1956). There are two mountains in this area, the tops of which are nearly four kilometres apart. Early settlers called the large northern one 'Big Rick' (today's Mount Colong, with the 'square top') and the smaller one to its south, which has a pointed top, 'Little Rick'. The official name of the latter today is Square Rock, a description of the shape of the cliffs around its base. The term 'rick' is a reference to the mountains' supposed resemblance to haystacks. A.L. Bennett made careful enquiries of his 
informant William Russell and recorded these names: Coolong for 'Little Rick' and the variants 'Gillingyang' and 'Gillinggang' for 'Big Rick'. Russell may have been annoyed by the white men's incorrect identification of the 'Big Rick' as Mount Coolong for he explained it as clearly as possible to Bennett on another occasion: 'Gillingang, Mtn Nth side of Mount Coolong' (Bennett, unpublished notes, c.1908-1914). Bennett's identification of this long-standing error was independently confirmed by Burragorang settler Martin Feld who recorded that 'Gill-in-gang' was the Gundungurra name for the peak 'now known as Mount Coolong'. Feld was the only person to record a 'meaning' for Gillingang suggesting, 'a high mountain, flat on top' (Feld 1900: 99). However, this is clearly a descriptive 'meaning'.

Table 3: Colong.

\begin{tabular}{|l|l|l|}
\hline Original spelling & Meaning & Reference \\
\hline Cullong & & $\begin{array}{l}\text { Barrett 1995: 15 } \\
\text { (recorded 1827) }\end{array}$ \\
\hline Collong & & Mitchell 1834 \\
\hline Gulong & 'wombat' & Hoben 1896: 1250 \\
\hline $\begin{array}{l}\text { Colong 'pronounced } \\
\text { Colung' }\end{array}$ & 'wombat' & Anon. 1899: 2 \\
\hline Coolong & 'wombat goes in' & Anon. 1900b: 95 \\
\hline Colung & 'home of the bandicoot' & Trickett 1900: 211 \\
\hline Gulang and Gulung & 'wombat' & $\begin{array}{l}\text { Mathews undated } \\
\text { 8006/3/10: 11, 14 }\end{array}$ \\
\hline Kaloong and Goolong & 'wombat' & Bennett c. 1908-14 \\
\hline Coolong & $\begin{array}{l}\text { 'valley of the native } \\
\text { bears' }\end{array}$ & Battye 1977: 2 \\
\hline
\end{tabular}

Source: The author.

\section{Tuglow}

Bennett recorded three separate references to this word.

1. 'tugga-going down low'.

2. 'Tuggaloe-a river going down a deep place or hole'.

3. 'Marrajung, the name of a place between Tugalo and Murrawone, the place of the hole'.

It is easy to identify 'Tuggaloe', the true three syllable version of Tuglow, as the Gundungurra name for what is now known as Horse Gully Creek (Central Mapping Authority 1982). The upper part of this creek, in wet weather, disappears underground into what are now known as the Horse Gully Sinkholes. 'Murrawone', 'the place of the hole' would, on first thought, appear to be 
the name for the main Tuglow Cave entrance. However, this entrance is only 200 metres away from the sinkholes, which does not leave much room for the other placename, 'Marrajung', between them. Although it does not appear on modern maps, Trickett's 1897 map of the Tuglow Caves area shows a locality, two kilometres south of the caves, called 'The Hole' (Cooper, Scott and VaughanTaylor, 1998: 25). Today's Tuglow Hole Creek is named after this 'hole' which is a striking natural depression or hollow in the ground (Peter Dykes, pers. comm. April 2012). Partial confirmation of this is provided by the proximity of this 'hole' to the 'Morong' locality (reflected in the current names Morong Creek and Morong Deep). It is quite feasible that 'Murrawone' (which probably sounded more like 'Murrawong') was corrupted to 'Morong'. Therefore Bennett's note 3 above is tentatively interpreted: 'Tuggaloe' was the Gundungurra name for the locality of Horse Gully Creek, including its sinkholes and cave entrances, and 'Murrawone' the name of 'the place of the hole' on Tuglow Hole Creek. It is not possible to exactly identify the location of 'Marrajung', a previously unrecorded placename, between 'Tuggaloe' and 'Murrawone'.

Gundungurra people were often named after the place where they were born (Russell 1914: 9). Placenames became people's names. William Russell told Bennett that the uncle who taught him the cultural stories, customs and placenames of his people was called Marrajung, because he was born at that place.

\section{Abercrombie Caves}

The creek flowing through Abercrombie Caves (shown on today's maps as Grove Creek) was known, at least as early as the 1840s, as Burrangilong Creek. This name was published in the Sydney Morning Herald on 25 April 1843 (Keck and Cubitt 1991: 18). When the artist Conrad Martens visited the caves in the following month he labelled his drawing of the main arch 'Burrangalong Cavern'. The cave complex was known for some years as the Burrangilong Caverns (also spelled 'Burrangylong' and 'Burran Galong'). It is likely that the Aboriginal name for Abercrombie Caves is close to 'Burrangylong'. Harold Koch (pers. comm. May 2013) has suggested the phonemic form of this name was barrankalang. The only published meaning for this word is 'bad tasting water' (Keck and Cubitt 1991: 51).

The name Abercrombie Caves was commonly used from the 1860s, as early visitors 'made the mistake of thinking that the creek flowing through the caves (Grove Creek) was the Abercrombie River' (Keck and Cubitt 1991: 7). The caves are five kilometres north of the Abercrombie River.

It is possible that analysis of the placename 'Burrangylong' could provide evidence of the language of the people whose country included Abercrombie 
Caves. When the Gundungurra Tribal Council made its Native Title claim in 1997 (claim NC 97/7) they included Abercrombie Caves within their country. This was disputed by Wiradjuri claimants. The Burra Burra clan of the Gundungurra speaking people, according to one early account, ranged over the area 'from the Abercrombie to Taralga and Carrrabungla' (MacAlister 1907: 82). If Burrangylong could be shown by linguistic analysis to be either a Gundungurra or Wiradjuri word, that would strengthen the claim of one group of descendants to the Abercrombie area.

\section{Discussion}

Of the five cave complexes discussed in this article only one, Wombeyan Caves, is officially referred to by an Aboriginal placename that closely resembles the original Aboriginal usage. 'Jenolan' and 'Colong' are misplaced toponyms in their usage for cave names. The spellings 'Jenolan' and 'Tuglow' are missing a syllable. The well authenticated Aboriginal name 'Burrangylong' was replaced with the English name of a river five kilometres away.

A good case could be made that Abercrombie Caves would satisfy the New South Wales state government criteria for dual naming, to re-establish the early recognition of its Aboriginal name. However, it is likely that there would be very strong resistance in the tourism industry to changing the well-established landmark name of Jenolan Caves to its correct Aboriginal placename or even of adding a $g$ to the end of 'Wombeyan'.

Bushwalkers are quite sensitive about any proposal to change the placenames associated in their minds with their personal journeys. ${ }^{4}$ They would probably not support changing Mount Colong to 'Gillingyang', Square Rock to 'Coolung', Morong Falls to 'Murrawong' and Tuglow Caves to 'Tuggaloe' (or more linguistically exact versions of these placenames).

In the same way that Jenolan Caves and Colong Caves were named after previously named topographic features near them, probably hundreds of Aboriginal placenames across Australia are the names of nearby places rather than those of the localities to which they have been applied.

The small sample of Aboriginal placenames discussed in this article includes a significant percentage which is lacking syllables in their current usage such as 'Jennowulan', 'Tuggalow', and 'Murrawong'. There are probably many

4 The author published an article (Smith 2006: 1, 4-5) which suggested that some of the placenames of the prolific nomenclaturist Myles Dunphy (1891-1985) in the southern Blue Mountains should be reevaluated. When this was reprinted in The Bushwalker, the magazine of the New South Wales Confederation of Bushwalking Clubs, subsequent issues carried letters expressing outrage from bushwalkers. 
hundreds of officially recognised Aboriginal placenames across Australia which are shorter than those originally used by Aboriginal people. In New South Wales, the Surveyor General Thomas Mitchell issued instructions to his staff in 1829 to spell Aboriginal placenames 'with as few letters as possible' and to avoid 'unnecessary consonants and dipthongs' (Andrews 1992: 73). However, his surveyors were not encouraged to eliminate vowels. Therefore, Mitchell's policy should not have caused Aboriginal placenames to be written with missing syllables. They were lost because non-Aboriginal people did not listen carefully enough to the Aboriginal pronunciation, particularly to softly or quickly spoken syllables. Where early records of Aboriginal placenames contain more syllables than those in current usage, these should generally be hypothesised as being more accurate. ${ }^{5}$

When the full version of an Aboriginal placename is established there is a better chance of working out its etymology. In Gundungurra country some placenames appear to be general descriptions of topography. The same placename could therefore have been used in different localities. Just as there are at least two 'Jenolans' there could well be other 'Tuggaloes', 'Benomeras' and 'Wombeyans'.

Another layer of meaning associated with placenames is their 'etiology'. Koch (2009: 118) defines this as 'the story behind the name'. He points out that:

In the long-settled areas of Australia, where the traditional languages have been poorly documented, we have very little hope of ever recovering the 'meaning' in the sense of the mythological story to which the name alludes (Koch 2009: 118).

Gundungurra descendants, and the settler communities which now live within their country, are fortunate that Mathews and Bennett did learn some of these mythological stories. The two Mount Jenolans may be connected with the travels of the creator ancestors the Bullens. Wombeyan Caves are likely to have been named after the 'tunnel' (real or imagined) created by a local variety of 'Rainbow Serpent' called Gurangatch. 'Binoomera's' meaning of 'holes' could also have a mythological connection. When the quoll ancestor Mirragan was hunting Gurangatch at Wombeyan and Jenolan Caves he poked his spear down into the underground caverns trying to capture him. These spear holes can still be seen at the caves today and are called potholes or dolines by non-Aboriginal people. It is possible that the word 'Binoomera' refers to these holes.

5 The following are some examples from Gundungurra country, sourced from the notebooks of Mathews and Bennett and early maps. The currently used placename is given first with the spellings from Gundungurra informants in brackets. Bimlow ('Bulla mullar'), Belloon Pass ('Belloonong'), Bullio ('Buli yoa'), Wingecarribbee River ('Winwingecarribbee'), Kanangra River ('Koo-nang-goor-wa'), Kanimbla Valley ('Kindingbula'), Marulan ('Murrawulan'), Mount Mouin ('Mee-oo-wun'), Duckmaloi ('Wan-dak-ma-lai'). 
We don't know the reason why the peak known as Little Rick or Square Rock is associated with the wombat. There is no recorded story explaining its origin and no resemblance between the shape of the mountain and a wombat. There may be a clue in one of the recorded meanings. A correspondent to Science of Man suggested that 'Coolong' meant 'wombat goes in' (Anon. 1900: 95). Perhaps during the gunyungalung a wombat ancestor did 'go in' the mountain. There is even a possibility, as Trickett (1900: 211) suggested, that the mountain was also 'the home of the bandicoot' in this lost story. Even apparently implausible placename meanings could contain a germ of truth relating to their etiology.

To conclude, it is hoped that analysis of the linguistic origins, etymology and distinctive features of Aboriginal placenames will be of assistance to those wishing to establish the original boundaries of language areas, such as Native Title claimants.

\section{Acknowledgements}

Thanks are due to Jim Barrett, Harold Koch and Luise Hercus for advice and to John Wylie for information on the cave systems and photos. Wilf Hilder (1934-2011), a former Counsellor of the Geographical Names Board (1967-1975), provided much information and stimulating discussions on nomenclature over the years.

\section{References}

Amery, R. 2002, 'Weeding out spurious etymologies: toponyms on the Adelaide Plains', in The Land Is a Map: Placenames of Indigenous Origin in Australia, Luise Hercus, Flavia Hodges and Jane Simpson (eds), Pandanus Books in association with Pacific Linguistics, Canberra: 165-180.

Andrews, A. 1992, Major Mitchell's Map 1834, Blubber Head Press, Hobart.

Anonymous undated [c.1899], [list of words headed 'Picton'] in Royal Anthropological Society of New South Wales papers, Mitchell Library, MSS, available on CD-ROM from Asia-Pacific Institute for Toponymy, Macquarie University.

— 1899, 'The Kowmung Caves', The Mountaineer, 5 May 1899.

- 1900a, 'Aboriginal names of places, etc., with their meanings', Science of Man, 21 June 1900: 80-82. 
Indigenous and Minority Placenames

- 1900b, 'Aboriginal names of places, etc., with their meanings', Science of Man, 23 July 1900: 95-98.

— 1907, 'Duckmaloi', Lithgow Mercury, 26 July 1907.

— 1956, 'Burragorang', The Waysider, March 1956.

Barrett, J. 1995, Life in the Burragorang, self-published, Glenbrook.

Battye, R. 1977, The Geology, History and Exploration of The Colong Caves, self published, Sydney.

Bennett, A. L., undated [c.1908-1914], Notes on Gundungurra language and culture, unpublished manuscripts, private collection.

Central Mapping Authority 1982, [map] Shooters Hill, second edition, Department of Lands, Bathurst.

Cooper, I., M. Scott and K. Vaughan-Taylor 1998, Tuglow Caves, Sydney University Speleological Society, Sydney.

Dyson, H, R. Ellis and J. James (eds) 1982, Wombeyan Caves, Sydney Speleological Society, Sydney.

Feld, M. 1900, 'Myths of Burragorang Tribe', Science of Man 3(6): 99.

Gerritson, R. 2010, 'The meaning of Morawa', Placenames Australia, June 2010: $1,3,7$.

Hanrahan, M. 1909, 'Aboriginal nomenclature', Lithgow Mercury, 28 June 1909.

Havard, W. 1933, The Romance of Jenolan Caves, Royal Australian Historical Society, Sydney.

Henderson, K. 1985, The Wombeyan Experience, Neptune Press, Geelong.

Hercus, L., F. Hodges and J. Simpson (eds) 2002, The Land Is a Map: Placenames of Indigenous Origin in Australia, Pandanus Books in association with Pacific Linguistics, Canberra.

Hoben, E.D. 1896, 'Round about the Mountains', Sydney Mail, 12 December 1896: 1246-1253.

Keck, K. and B. Cubitt 1991, Abercrombie Caves, Cave Chronicles, Abercrombie Caves Historical Research Group, Trunkey Creek.

Koch, H. 2009, 'The methodology of reconstructing Indigenous placenames. Australian Capital Territory and south-eastern New South Wales', in 
Aboriginal Placenames: Naming and Re-naming the Australian Landscape, Harold Koch and Luise Hercus (eds), ANU E Press and Aboriginal History Inc., Canberra: 115-171.

Koch, H. and L. Hercus (eds) 2009, Aboriginal Placenames: Naming and Renaming the Australian Landscape, ANU E Press and Aboriginal History Incorporated, Canberra.

MacAlister, C. 1907, Old Pioneering Days in the Sunny South, Charles MacAlister Book Production Committee, Goulburn.

Mathews, R. H. undated, Unpublished Notebooks, National Library of Australia, MS 8006.

- 1901, 'The Gundungurra language', Proceedings of the American Philosophical Society XL: 140-148.

- 1908, 'Some mythology of the Gundungurra Tribe, New South Wales', Zeitschrift fur Ethnologie 40: 203-206.

- 2003, Some Mythology and Folklore of the Gundungurra Tribe (edited by Jim Smith), Den Fenella Press, Wentworth Falls.

McCarthy, F. 1959, New South Wales Aboriginal Place Names and Euphonious Words, with their Meanings, Australian Museum, Sydney.

Mitchell, T. 1834, Map of the Colony of New South Wales, Engraved by John Carmichael, London.

Nurse, B. 1982, 'A History of the Wombeyan Caves Area', in Wombeyan Caves, H. Dyson, Ross Ellis and Julia James (eds), Sydney Speleological Society, Sydney: 1-12.

Padley, J. 1892, Lithgow District Nomenclature, Unpublished typescript, Mitchell Library, 981.5/P.

Roberts, J. H. 1886, A World Tour, The Author, Abergale.

Russell, W. 1914, My Recollections, Camden News, Camden.

Smith, J. 1992, Aborigines of the Goulburn District, Goulburn District Historical Society, Goulburn.

- 2006, 'Myles Dunphy and William Cuneo, two misguided nomenclaturists of the Blue Mountains', PlacenamesAustralia, March 2006: 1, 4-5. Reprinted in TheBushwalker 31(3), Winter 2006: 9-10. 
- 2008, 'Gundungurra Country', PhD thesis, Department of Indigenous Studies, Macquarie University.

Thorpe, W. 1927, List of New South Wales Aboriginal Place Names and Their Meanings, Australian Museum, Sydney.

Tindale, N. 1974, Aboriginal Tribes of Australia, University of California Press, Berkeley.

Trickett, O. 1899, Guide to the Jenolan Caves, Government Printer, Sydney.

- 1900, 'Report on Colong Caves', in Annual Report of the Department of Mines for 1899, Votes and Proceedings of the Legislative Assembly, New South Wales: 211-212. 
This text taken from Indigenous and Minority Placenames: Australian and International Perspectives, Edited by Ian D. Clark, Luise Hercus and Laura Kostanski, published 2014 by ANU Press, The Australian National University, Canberra, Australia. 